\title{
Development of Health Integrative Thematic Textbooks (Batik) To Provide Health Education in Elementary Schools
}

\author{
I Ketut Sudiana', N. Adiputra ${ }^{2}$, Putu Budi Adnyana ${ }^{3}$ \\ 1Jurusan Kimia FMIPA Undiksha, Singaraja Bali, Indonesia, ${ }^{2}$ Fakultas Kedokteran Universitas Udayana, \\ Denpasar Bali, Indonesia, 3Jurusan Biologi FMIPA Undiksha, Singaraja Bali, Indonesia \\ e-mail: sudi.ana@undiksha.ac.id, nadip2003@yahoo.com, budi@undiksha.ac.id
}

\begin{abstract}
This research aims to develop health integrative thematic textbooks (BATIK). The method used is the Research and Development model of Borg \& Gall. Based on the research, it obtained an integrated health education material following the PHBS indicator of school. Integration using two patterns, explicitly through the subtitle "Ayo Lakukan Hidup Bersih dan Sehat," and implicitly integrated into the text, the use of children's songs and illustrated images that contain health education. The BATIK assessment at the validation and readability stage obtained the following results: (1) validation by experts obtained very good, (2) validation by elementary school teachers obtained very good, (3) a one to one evaluation readability test obtained good, and (4) a small group evaluation readability test obtained very good. Based on the results of the validation and readability test, it shows that the quality of BATIK is good, so it is suitable to be used in thematic learning in elementary schools.
\end{abstract}

Keywords: Thematic; Insertion; Health Education

\section{Introduction}

Education is an important social determinant for health (Higgins et al., 2008). Education plays an important role in health promotion (Jourdan, 2011). The relationship between education and health is closely related (Leger et al., 2010). The relationship between the quality of education and health is reciprocal (Chesney, 2014). Students must be healthy to be educated, and they must be educated to stay healthy (Allensworth at al., 1995). Children need an optimal health status to be able to take lessons well. Good health status supports children's success in learning (Smith, 2003). Schools cannot educate and succeed in learning if students are not healthy (Michigan State Board of Education, 2004). Schools play a role as an entry point for changes in healthy behavior. The role of schools is significant in changing and providing an understanding of healthy living behaviors (Achadi et al., 2010). Health interventions can have a positive impact on student health and academic achievement (Dilley, 2009). Therefore, health education is essential to be given to school children in order to have a clean and healthy life behavior (PHBS).

However, in Indonesia, health education in schools is still lacking. The attention of the school community and the community towards health efforts in schools is still low (Prasetyo, 2009). As a result, healthy behavior among students is bad. As proof, many illnesses suffered by children can reappear during school (Rosso and Arlianti, 2009). Poor nutrition status of children (Sartika, 2011). Healthy behavior of school-age children is still low (Depkes, 2008; Kemenkes, 2013). Children behave in neglect or negate breakfast (Rampersaud at al., 2005; Matthys at al, 2006); students often experience food poisoning due to consuming children's snacks. schools (PJAS) that are not healthy (BPOM RI, 2009; BPOM RI, 2011), and schoolage children lack physical activity (Kiess at al., 2004). The evidence presented describes school-age children who are at risk of developing diseases and health problems (population at risk) (Clemen-Stone et al., 2002). This risk factor has implications for schoolchildren's learning achievement. Every health risk can affect academic success. The more health risks students have, the less likely they will be to succeed in school. Improving health factors can help improve academic achievement (Sorhaindo and Feinstein, 2006; Dilley, 2009). In connection with that, health education is very urgent, given as early as possible. Studies have found that promoting and building healthy behaviors for younger people is very useful for their 
growth and development. Health Education in schools helps students learn the skills they will use to make healthy choices throughout their lives (Greensprings School, 2018).

Since the 2013/2014 academic year in Indonesia, the 2013 curriculum has been implemented using an integrated thematic learning strategy (Kemdikbud, 2013a). This strategy provides an opportunity to incorporate (integrally) health education materials into learning themes. Health education must be provided thematically to children according to their growth process (Michinaga, 2013). Innovations in the form of a strategy of integrating health education into the theme of health learning have never been done in learning. This strategy has the opportunity to be carried out in good learning, from now on referred to as the integrative health thematic strategy (STIK), which is a learning strategy that allows students to acquire knowledge, attitudes, and skills regarding health, achieve health literacy, implement health-promoting behaviors, and promote people's health others (Centers for Disease Control and Prevention, 2013).

In implementing STIK, teaching materials need to be supported. Namely the integrative thematic textbook health (BATIK), which is the result of the development of the 2013 Curriculum Integrated Thematic Book published by the Indonesian Ministry of Education and Culture. The intended development is integrating health education material into learning themes using insertion methods (Tayar, 1997; Sugirin et al., 2013).

The superiority of BATIK teaching materials is the students get health education without reducing the students' competencies as demanded by the curriculum and do not add to the learning burden of students considering the learning burden of primary school children according to the 2013 curriculum is heavy. So, what is new (novelty) from this research development is the production of teaching materials containing health education, abbreviated as BATIK, in which the health education content is integrated into the learning theme.

Health is a basic human right and is a social investment (WHO, 2009). Health is vital for everyone, including students. Healthy students are better students than those who are sick (Basch, 2011). Health education for children is mandated by Undang-Undang Nomor 20 Tahun 2003 about the National Education System, which states that the function of national education is not only transferring knowledge but also building the health or healthy behavior of students. Likewise, Undang-Undang Nomor 36 Tahun 2009 about Health mandates that school health be held to improve the ability of healthy living for students in a healthy environment so that students can learn, grow and develop harmoniously and as high as possible to become quality human resources. In Indonesia, health education in schools, especially Elementary School (SD) levels, is still lacking, only relying on the Usaha Kesehatan Sekolah (UKS) program (Handayani at al., 2015). Health education is not yet a stand-alone subject, so students do not get enough information about health.

The study on the curriculum in 2013 obtained the number of hours of classroom lessons in the second-grade of elementary school is 32 hours per - week. With such number of study hours, the learning burden of elementary school children is too heavy (Kemdikbud, 2013b). With such a heavy learning burden, it is not possible to provide health education by bringing up health education subjects, which increases student learning.

In Indonesia, since the 2013 academic year, the 2013 Curriculum implemented. The implementation of this curriculum uses thematic learning. Thematic learning is also called integrated learning (Sulhan, 2010). Thematic learning is learning activities by integrating the material of several subjects into one theme/topic of discussion in an integrated manner. Thematic learning provides flexibility (autonomy) for teachers to develop learning themes in order to achieve learning objectives, including the possibility of using health themes or integrating health education into learning. By using health themes or integrating health education into learning themes, students can obtain health education without having to increase hours of study. For this purpose, teachers are required to have the skills to design learning strategies that can accommodate health education that is needed by students in learning themes. 


\section{Methods}

This research is a research and development (Borg \& Gall, 1989; Sugiyono, 2012) with restrictions tailored to the needs of the research, covering seven steps, namely (1) potential and problems, (2) data collection (3) design products, (4) design validation, (5) design revisions, (6) product legibility testing, (7) design revisions. The seven steps of development are simplified into four steps of development.

1) The data collection stage carried out to determine the learning needs in the field.

2) The planning stage, starting with the preparation of the BATIK design and making the mapping of learning materials.

3) The product development stage, starting with the collection of materials, illustrations/photographs, material management, and finally, BATIK production.

4) The validation and trial phase. BATIK that has been produced is then evaluated by validating experts and practitioners (users). After it is declared valid, it is continued with the student's trial use (readability test).

\subsection{Research Subject}

The research subjects in this development research were the second-grade students of Undiksha Laboratory Elementary School, consisting of six students as one to one evaluation research subjects and twelve students as research subjects in small group evaluation trials. The determination of six students as one-on-one trial subjects was done by purposive sampling, while a simple random sampling technique determined the subjects of small group trial studies.

\subsection{Research Object}

The object of research in this development research is the content of health education integrated into the learning theme, theme 7: "Merawat Hewan dan Tumbuhan."

\subsection{Type of Data}

In this research development, there are two types of data needed, qualitative and quantitative data. The type of qualitative data was obtained from interviews with second-grade elementary school teachers, suggestions, and ministries provided by experts (validators) and students. The quantitative data type was obtained from the results of scoring the validation questionnaire sheet.

\subsection{Data Collection Technique}

This development research used non-test data collection techniques. Non-test data collection techniques used were interviews and questionnaires. Data collection techniques using interviews were used to interview teachers to analyze the needs associated with the preparation of BATIK teaching materials. Questionnaire data collection techniques are used to validate BATIK teaching materials by experts and practitioners (users), as well as readability tests by students.

\subsection{Data Analysis Technique}

In the preliminary research stage, qualitative descriptive analysis was used to encapsulate the potential opportunities to integrate health education into learning themes, while in the research stage, the BATIK teaching material development of research data was analyzed qualitatively and quantitatively.

\section{Results and Discussion}

\subsection{Requirements Analysis}

The initial step in researching the development of teaching materials is to conduct a needs analysis. From the needs analysis, the following data are obtained. Health education materials provided in schools are still lacking; teachers consider it important to provide health education in elementary schools, teachers believe that they do not have sufficient knowledge 
or competencies to teach health education. Health education materials that are integrated must be relevant to the theme, so as not to interfere with learning objectives.

Health education materials needed by students or important to be given to elementary students are Washing hands with soap (CTPS), bathing and shampooing, cleaning and cutting nails, brushing teeth, regular exercise, defecating (BAB) and urinating (BAK) ) in latrines/toilets, drinking water, littering in rubbish bins, eradicating mosquito larvae, consuming fruits and vegetables every day, consumption of healthy snacks (not eating at random), healthy canteens, fond of eating fish, body growth (measuring body weight (measuring BB) and height (TB), environmental cleanliness.

In the school facilities and infrastructure are available to support the continuation of health education for elementary students, such as the UKS Room and its accessories, garbage bins or trash bins, handwashing places with soap (CTPS), some media images containing health messages ( such as no smoking, littering in place, clean, healthy base).

The lessons learned are integrative thematic learning with a scientific approach (Kemdikbud, 2013a). Integrated thematic learning provides opportunities to integrate health education. All themes have the opportunity to be integrated into health education.

Health education is important for school-age children. Some supporting statements indicate that the importance of the link between education and health is as follows. Suyatno (2014) mentioned that the integration of knowledge is a necessity for printing students who have integrative personalities. Moreover, the principles that guide the improvement of health in schools can be applied among elementary school students (Gadin et al., 2009). Research integrating health education into the mathematics curriculum conducted by Bruselius-Jensen and Bunde (2014) found that integration as intended results in good learning outcomes in mathematics and health education. Irwandi et al. (2016) stated that strategies for fostering healthy behavior in students are through learning in the classroom by integrating knowledge about PHBS into learning. Effective health education helps students better in their studies (Schoener et al., 1988). Thus, the Integration of certain methods into learning themes can use the insertion method. There are two insertion patterns, namely, explicit and implicit (Tayar, 1997; Sugirin, 2013).

Important health education materials needed by students in grade II are washing hands with soap (CTPS), bathing and shampooing, cleaning and cutting nails, brushing teeth, regular exercise, defecating (BAB) and urinating (BAK) in latrines/toilets, drinking water, littering in trash cans, eradicating mosquito larvae, consuming fruits and vegetables every day, consuming healthy snacks (not eating at random), healthy canteen/stalls, fond of eating fish, growing body (measuring body weight (BB) and height (TB), and environmental cleanliness (Tim Pembina UKS Pusat. 2010; Kemenkes, 2011).

Teachers need to know the characteristics of students so that teachers can help optimize the growth and development of students through education and learning. Teachers in schools must be able to choose teaching materials that are appropriate to the characteristics of their students. The characteristics of elementary school-age children are as follows. (1) School-age children tend to learn concrete, integrative/holistic, and hierarchical (Sukayati and Wulandari, 2009). In connection with these characteristics, it is easier for elementary school students to learn through integrated thematic learning. (2) School-age children like to play, like to move, like to work in groups, like to feel or do something directly (Sumantri and Syaodih, 2007; Kurniawan, 2011; Desmita, 2011). Related to these characteristics learning in elementary schools uses a scientific approach in cooperative learning settings. (3) School-age children are a group at risk of health problems (population at risk). As an age group prone to illness and illness or health problems, it is essential to provide health education to elementary schoolage children. (4) One of the needs of elementary school-age students associated with the task of development is to develop a healthy attitude about oneself as a living creature (Hurlock, 2002). In this connection, relevant health education materials are provided to elementary school-age students. (5) School-age children are in a period of rapid growth and development, are very sensitive to stimuli so that they are easily guided, directed, and instilled good habits, including habits for clean and healthy living behavior. 


\subsection{BATIK Product Description}

The focus of BATIK development is the integration of health education materials into learning themes. From the BATIK design aspect, there is no difference from the design in the Integrated Thematic Book published by the Ministry of Education and Culture Book Center.

Based on the results of the needs analysis through curriculum study (syllabus), literature review, the study of the characteristics of second-grade elementary school students, the BATIK product design was made as a result of the development of the Integrated Thematic Book published by the Ministry of Education and Culture Book Center. The results of the needs analysis include continuing to facilitate learning with a scientific approach in the setting of cooperative learning. Besides, it should pay attention to the characteristics of elementary school children who tend to learn concretely, integratively/holistically, and hierarchically, health education materials that are integrated and have no implications for the occurrence of increasing the burden of student learning, facilitate learning activities joyful learning.

The method chosen to integrate the content of health education materials is the insertion method (Tayar, 1997; Sugirin, 2013). There are two insertion patterns, namely explicitly through the subtitle "Ayo Lakukan Hidup Bersih dan Sehat," and implicitly integrated into the text/reading and the use of children's songs with health content. BATIK contains text descriptions of health-related teaching materials that are equipped with illustrated images and layout designs that are made attractive. Thus, BATIK is a teaching material as well as being able to be seen as a medium of the image, so BATIK is attractive to elementary students. Image illustration is a teaching tool that can attract students' interest in learning effectively (Sudjana, 2001). Students better understand a concept if learning is presented not only with words but equipped with pictures (Mayer, 2009).

The nature of the insertion of health education into the learning theme using the insertion method presented subtly, making students almost imperceptible/noticeable, that in fact, they have received health education.

The design of BATIK teaching materials is no different from the Integrated Thematic Book of the Ministry of Education and Culture because it still uses the mapping of KI, KD and learning indicators, and the same themes. Likewise, the scientific approach to learning is characterized by $5 \mathrm{M}$ activities, observing, asking, reasoning, trying, and communicating. The BATIK structure is designed to facilitate learning with a scientific approach that can provide meaningful learning experiences for students. The learning experience packaged in subtitles Ayo Membaca, Ayo Menanya, Ayo Mengamati, Ayo Menulis, Ayo Beraktivitas, Ayo Bercerita, Ayo Berkreasi, Ayo Berlatih, Ayo Bermain Peran, dan Ayo Bernyanyi, and subsection of health education Ayo Lakukan Hidup Bersih and Sehat. At the end of each sub-theme, there is a selfreflection sheet with the icon Sekarang Aku Bisa, and at the end of each lesson, there is a column for parents with subtitles Ayo Belajar Bersama Orang Tua.

\subsection{Product Validation and Revision Data}

The first products that have been compiled in the form of BATIK teaching materials and BATIK Supplements are given to content experts, learning technology and media, and to grade II elementary school teachers for validation. This validation is carried out to find out how good the quality and feasibility of the products developed by researchers. This validation uses scoring ordinal scale (1 to 4 ).

The BATIK book is validated by two experts, namely content experts, and educational technology and media experts. The aspects assessed from the BATIK book are the appropriateness of the content, linguistics, presentation component, and graphics. Based on the results of the validation of the four aspects obtained an average score of 3.72 (very good category). The BATIK teaching materials are declared to be suitable for use or field trials with revisions, as suggested. Revisions include the appearance of a cover image made simple with a more organized image display. Page margins are arranged the same. Each separator is made with more extensive spaces or different colors, and each activity is separated by a different color, the presentation of the image is first followed by an explanation, examples of vegetable images and fruit plus the types of vegetables and fruit known to students 


\subsection{Teacher Validation Data and Product Revision}

Teachers who become validators in this research product are two elementary school second-grade teachers as users. The aspects assessed are the same, namely the appropriateness of the content, linguistics, presentation component, and graphic. Based on the results of validation by elementary school teachers (users) obtained an average score of 3.69 (very good category). BATIK teaching materials are declared suitable for use or field trials with revisions according to suggestions.

Products that have been validated by elementary school teachers (users) are revised according to the comments and suggestions given. The user suggests that the image quality is improved, and the dividing line is filled between the text part of the textbook and the page number.

\subsection{Field Trial and Product Revision Data}

The product of BATIK teaching materials that have been validated by content experts and media experts and learning design and elementary school teachers were revised according to comments and suggestions then tested in the field to find out students' opinions related to the quality of BATIK teaching materials. Field trials or readability tests are conducted on grade II students of Undiksha Laboratory Elementary School. Readability test activities carried out twice. First, one-on-one evaluations and second, small group evaluations. Six elementary school students followed a one-on-one legibility test in grade II. The six students learn by using BATIK teaching materials guided by the teacher. Learning activities are more focused on understanding the inserted health education material. During learning, students are asked to convey if there are words or terms they do not understand. If students do not understand some words or terms, the teacher takes notes, and the teacher gives an explanation or replaces the words or terms with words or other terms that the students understand. On the last day of learning activities, students fill out the BATIK teaching material quality questionnaire.

Based on the results of the questionnaire input by students, the assessment of BATIK teaching materials in the group of low, medium, and high ability students ranged from 3.33 to 3.34 or a mean score of 3.39 (good category). Found several words or terms that are not understood, such as the word latrine, at least, and consume. The three words are replaced by other words or terms understood by students, such as latrine replaced by the word WC/toilet, at least replaced with the minimal word, and consuming is replaced by the word eat.

BATIK teaching materials, after being revised based on one-on-one readability tests, readability tests were again carried out in the same way in small groups. Twelve students attended the small group readability test activity. The results of the readability test in the small group were an average score of 3.91 (very good category). In the small group readability test, there are no more words or terms that are not understood by students.

Health education or health promotion in schools has not shown encouraging results. It is evident from the following facts. (1) There are still many illnesses suffered by children (0-5 years) that can reappear during the school period, especially in the early days of school (6-8 years). (2) The nutritional status of school children is still poor. School children face multiple nutritional problems (malnutrition problems are still not completely resolved, while overnutrition problems have emerged). (3) The healthy behavior of school-aged children is still low. (4) School-age children like to neglect or exclude breakfast, preferring snacks. (5) Schoolage children lack physical activity (sedentary behavior). Based on this, the description of school-age children is a group that is vulnerable to health problems or called the population at risk. As a group at risk of health problems (population at risk), it is crucial to be given health education.

Aside from being a population at risk, the importance of health education for elementary school-age students is also related to their developmental task, namely to build a healthy attitude about themselves as a living creature (Hurlock, 2002). Health education is very relevant to be given at elementary school age because school-age children are in a period of rapid growth and development, susceptible to stimuli so that they are easy to be guided, directed, and instilled good habits, including habits to behave in a clean and healthy life. 
The learning burden of elementary school children is too heavy, which is 32 hours per week. Therefore, it will increase the burden of learning if we have to add hours to bring up health education subjects in order to provide health education to students. In this regard, efforts can be made to integrate health education materials into learning themes with insertion methods (Sugirin, 2011). There are two insertion patterns, namely explicitly through the subtitle "Ayo Lakukan Hidup Bersih dan Sehat," and implicitly integrated into the text/reading and the use of children's songs with health content. The nature of the insertion of health education into learning themes that are presented subtly makes students almost imperceptible/noticeable, that has received health education.

The integration of health education materials into learning themes with the insertion method is realized in the form of BATIK teaching materials as a product of development. BATIK contains text descriptions of health-related teaching materials that are equipped with illustrated images and layout designs that are made interesting.

Based on the needs analysis, it was found that relevant health education materials were integrated into the theme of class II learning elementary school theme 7. "Merawat Hewan dan Tumbuhan" is a health education material that is adjusted to the PHBS indicators of the school setting, is contextual, and is following the development and characteristics of grade II elementary school students. The health education material chosen to be integrated into the chosen learning theme is fundamental. It is expected to provide motivation and encouragement to contain health messages about What, How, Why, and For What.

According to the Team of Trustees of the UKS Health Education Center in SD/MI, health education materials for elementary school students include personal hygiene, the freshness of the body, healthy food, environmental health, infectious diseases and immunizations, and problem-free schools (Kemenkes, 2011). By paying attention to the level of development of grade II elementary school students, adjustment to the learning theme "Merawat Hewan dan Tumbuhan," the health education material integrated into BATIK teaching materials was conducted. Personal hygiene (skin, hair, ears, teeth, hands, feet, and nails), habits exercise or physical activity, adequate sleeping habits, brushing teeth, washing hands with soap (CTPS), balanced nutrition and menu, getting breakfast, eating vegetables and fruit, drinking water, throwing garbage in the trash, defecating (defecating) ) and urinating (BAK) in a toilet/toilet, snacks in a healthy school canteen, no snacks on the side of the road, measuring height (TB) and body weight (BB), eradicating mosquito larvae with 3M (Menguras = drain, Menutup = Close, Mengubur $=$ bury).

The results of BATIK validation by two experts (content experts and media experts and learning design) obtained an average score of 3.72 (very good category). However, validation by two elementary school teachers in grade II obtained an average score of 3.69 (very good category). Test one to one evaluation (one to one evaluation) obtained an average score of 3.39 (good category) and increased in the small group evaluation results (small group evaluation) obtained an average score of 3.91 (very good category). The results of the validation test and the readability test indicate that BATIK meets the eligibility criteria for use in learning. As teaching material, the material presented in BATIK is following the 2013 curriculum and has additional material in the form of health education.

\section{Conclusion}

This development research resulted in the development of BATIK products that meet the eligibility criteria as teaching material seen from the aspects of the appropriateness of the content, the feasibility of linguistics, the feasibility of the presentation, the feasibility of graphics, and the readability aspect. Thus, BATIK can be used as teaching material in carrying out learning in class.

Teachers in primary schools can use BATIK teaching materials, because, in addition to providing teaching materials according to the 2013 Curriculum, BATIK also provides health education to students. The government can use the results of this research as a policy base to provide health education in primary schools and to promote health in schools. 


\section{Acknowledgment}

Thank you to Direktorat Riset dan Pengabdian Masyarakat, Kementerian Ristekdikti who has funded this research through Penelitian Disertasi Doktor (PDD) scheme with Research Contract Number: 173/UN48.15/LT/2018.

\section{References}

Achadi, E., S.A. Pujonarti, T. Sudiarti, Rahmawati, Kusharisupeni, Marditilah, W.K.Y. Putra. (2010). Sekolah Dasar Pintu Masuk Perbaikan Pengetahuan, Sikap, dan Perilaku Gizi Seimbang Masyarakat. Jurnal Kesehatan Masyarakat Nasional. 5 (1): $42-48$.

Allensworth D., J.Wyche, E.Lawson, dan L. Nicholson. (1995). Defining a Comprehensive School Health Program: An Interim Statement. Committee on Comprehensive School Health Programs, Division of Health Science Policy, Institute of Medicine. Washington, D.C: National Academy Press.

Basch, C.E. (2011). Healthier Students are Better Learners: High-Quality, Strategically Planned, and Effectively Coordinated School Health Programs Must be a Fundamental Mission of Schools to Help Close the Achievement Gap. Journal of School Health. 81(10):650-662.

Borg, W.R. \& Gall, M.D. Gall. (1989). Educational Research: An Introduction, Fifth Edition. New York: Longman

BPOM RI. (2009). Sistem Keamanan Pangan Terpadu Pangan Jajanan Anak Sekolah. FoodWatch. Vol.1:1 - 4.

BPOM RI. (2011). Peduli Pangan Jajanan Anak Sekolah. Info POM. 12(1):1-4.

Bruselius-Jensen, M. dan A. Bunde. (2014). Integrating Health Education In The School Curriculum - Findings From A Primary School Intervention. Conference: ECER 2014, The Past, the Present and the Future of Educational Research. (serial online) [cited 2018 Juni 1]. Available from: URL: http://www.eera-ecer.de/ecerprogrammes/conference/19/contributi on/31040/

Centers for Disease Control and Prevention. (2013). Results from the School Health Policies and Practices Study 2012. School Health Policies and Practices Study. U.S. Department of Health and Human Services.

Chesney, M.L. (2014). Education an Important Prescription for Health, jpedhc, 28 (5): 374-375

Clemen-Stone, S., S.L. McGuire, dan D.G. Eigisti. (2002). Comprehensive Community Health Nursing: Family, Agregat, dan Community Practice. 6th Edition. St. Louis: Mosby, Inc.

Depkes. (2008). Riset Kesehatan Dasar (Riskesdas) 2007. Jakarta.

Desmita. (2011). Psikologi Perkembangan Peserta Didik. Bandung: Rosdakarya.

Dilley, J. (2009). School-based Health Interventions and Academic Achieviement. Washington State Board of Health. Research Review. Ashington State Department of Health.

Gadin, K.G., G. Weiner dan C. Ahlgren. (2009). Young Students as Participannts in School Health Promotion: An Intervention Study in A Swedish Elementary School. Int $J$ Circumpolar Health, 68(5): 498-507 (serial online) [cited 2018 Juni 1]. Available from: URL: https://www.diva-portal.org/smash/get/ diva2:279759/FULLTEXT01.pdf

Greensprings School. (2018). Health Education in Nigerian Schools: Why it is Important. (serial online) [cited 2018 September 24]. Available from: URL:http://enrol.greenspringsschool.com/health-education-in-nigerian-schools/

Handayani, O. W. K., T. Rahayu, I Budiono. R. Windraswara, L. Fausi, N. Siyam, and L. Mc Cuaig. (2015). Health Promotion Models to Reduce Childhood Obesity in Elementary School: A Comparison Study between Indonesia and Australia. JSRR,7(1):1-10.

Higgins, C., T. Lavin, \& O. Metcalfe. (2008). Health Impacts of Educationa review. Institute of Public Health in Ireland.

Hurlock, B.H. (2002). Psikologi Perkembangan: Suatu Pendekatan Sepanjang Rentang Kehidupan. Edisi Kelima. (Istiwidayanti dan Soedjarwo, Pentj). Jakarta: Erlangga.

Irwandi, S., N. Ufatin dan Sutoni. (2016). Peran Sekolah dalam Menumbuhkembangkan Perilaku Hidup Sehat pada Siswa Sekolah Dasar (Studi Multi Situs di SD Negeri 6 
Mataram dan SD Negeri 41 Mataram Kota Mataram Nusa Tenggara Barat. Jurnal Pendidikan: Teori, Penelitian, dan Pengembangan. 1(3): 492-498.

Jourdan, D. (2011). Health education in schools. The challenge of teacher training. SaintDenis: Inpes, coll.

Kemdikbud. (2013a). Mata Pelajaran: Konsep Pendekatan Scientific. Mata Diklat: 2. Analisis Materi Ajar Jenjang: SD/SMP/SMA.Diklat Guru dalam Rangka Implementasi Kurikulum 2013.

Kemdikbud, (2013b). Kerangka Dasar dan Struktur Kurikulum 2013. Jakarta

Kemenkes. 2011. Modul Mandiri Pendidikan Kesehatan di Sekolah Dasar/Madrasah Ibtidaiyah. Jakarta.

Kemenkes. (2013). Riset Kesehatan Dasar 2013. Jakarta.

Kiess,W., K.Raile, T. Kapellen, R. Pfaeffle, E. Keller, S. Blüher, dan A. Böttner. (2004). Multidisciplinary Management of Obesity in Children and Adolescents-Why and How Should It Be Achieved? In: Kiess W, Marcus C, Wabitsch M (eds). Obesity in Childhood and Adolescence. Pediatr Adolesc Med. Basel, Switzerland: Karger AG. Vol. 9:194 206.

Kurniawan, N. (2011). Karakteristik dan Kebutuhan Pendidikan Anak Usia Sekolah Dasar. (serial online) [cited 2016 Mar. 31]. Available from: URL: http://dgirlss.wordpress.com/karakteristik-dan-kebutuhan-pendidikan-anak -usiasekolah-dasar-oleh-nursidik-kurniawan-a-ma-pd-sd/.

Leger, L.St., I. Young, C. Blanchard, \& M. Perry. 2010. Promoting Health in Schools from Evidence to Action. International Union for Health Promotion and Education (IUHPE). Website: www.iuhpe.org

Matthys, C, S. De Henauw, M. Bellemans, M. De Maeyer, G. De Backer. (2006). Breakfast habits affect overall nutrient profiles in adolescents. Public Health Nutr. 10(4): 413-421.

Mayer, R. E. (2009). Multimedia Learning: Prinsip-Prinsip dan Aplikasi. Yogyakarta: Pustaka Pelajar.

Michigan State Board of Education. (2004). Policy on Comprehensive School Health Education. June 8, 2004. Millington, N.T. (2011). Using Songs Effectively to Teach English to Young Learners. Language Education in Asia. 2 (1): 134 - 141.

Michinaga, M. 2013. Current Status and Issues of School Health, JMAJ 56(4): 211-219

Prasetyo, Y.B. (2009). Evaluasi Kesejahteraan Sekolah dengan Pendekatan Model Sekolah Sejahtera di SMP 4. Laporan Penelitian. Fakultas IImu Kesehatan Universitas Muhammadiyah Malang.

Rampersaud, G.C., M.A. Pereira, B.L. Girard, J. Adams dan J.D. Metzl. (2005). Breakfast habits, nutritional status, body weight, and academic performance in children and adolescents. Journalof The American Dietetic Association. 105 (5): 743-760.

Rosso, J.M.D dan R. Arlianti. (2009). Investasi untuk Kesehatan dan Gizi Sekolah di Indonesia. Basic Education Capacity-Trust Fund.

Sartika, R.A.D. (2011). Faktor Risiko Obesitas pada Anak 5-15 Tahun di Indonesia. Makara Kesehatan. 15 (1): 37-43.

Schoener, J., F. Guerrero \& B. Withney. 1988. The Effects of The Growing Healthy Program upon Children's Academic Performance and Attendance in New York City. Report from The Office of Research, Evaluation and Assessment to The New York City Board Education.

Smith, J. (2003). Education and Public Health: Natural Partnersin Learning for Life. Association for Supervision and Curriculum Development (ASCD). USA: Alexandria,Virginia.

Sorhaindo, A. dan L. Feinstein. (2006). What is The Relationship Between Child Nutrition and School Outcomes? Wider Benefits of Learning Research Report No. 18, London: Centre for Research on the Wider Benefits of Learning.

Sudjana, N. (2001). Media Pengajaran. Jakarta: Sinar Baru Algensindo.

Sugirin, S. Sudartini, Suciati, L. Nurhayati. (2011). A Studi of Cultural Integration in The English Textbooks for Junior High Schools. LITERA, 10 (2): 235-46. 
Sugirin, A. Widyantoro, S., Sudartini, (2013). Pengembangan Model Pengintegrasian Pendidikan Karakter dalam Pembelajaran Bahasa Inggris Di SMA. Laporan Penelitian. UNY. 2013.

Sugiyono. (2012). Metode Penelitian Kuantitatif, Kualitatif, dan R \& D. Bandung: Alfabeta

Sukayati \& S. Wulandari. 2009. Pembelajaran Tematik di SD. Pusat Pengembangan dan Pemberdayaan Pendidik dan Tenaga Kependidikan Matematika. Direktorat Jenderal Peningkatan Mutu Pendidik dan Tenaga Kependidikan. Departemen Pendidikan Nasional.

Sulhan, N. 2010. Pendidikan Karakter pada Anak. Surabaya: SIC dan Yayasan AI-Azhar Kelapa Gading Surabaya.

Sumantri, M.D. dan N. Syaodih. 2007. Perkembangan Peserta Didik. Jakarta: Universitas Terbuka.

Suyatno. (2014). Integrasi Ilmu di Sekolah Dasar (Studi Kasus Kurikulum Terpadu di SDIT Lukman Al-Hakim Surakarta). (serial online) [cited 2018 Mei 31]. Available from: URL: http://ejournal.umm.ac.id/index.php/jp2sd/article/ view/2727/3414

Tayar,Y. (1997). Metodologi Pengajaran Agama dan Bahasa Arab. Jakarta: Raja Grafindo Persada.

Tim Pembina UKS Pusat. 2010. Cara Melaksanakan UKS di Sekolah dan Madrasah. Pusat Pengembangan Kualitas Jasmani Depdiknas. Jakarta.

WHO (2009). Milestones in Health Promotion: Statements from Global Conferences. Geneva. 